OnLine Journal of Biological Sciences 7 (2): 52-65, 2007

ISSN 1608-4217

(C) 2007 Science Publications

\title{
Assessment of Constructed Wetland Biological Integrity Using Aquatic Macroinvertebrates
}

\author{
${ }^{1}$ C. Galbrand, ${ }^{2}$ I.G. Lemieux, ${ }^{2}$ A.E. Ghaly, ${ }^{1}$ R. Côté and ${ }^{2}$ M. Verma \\ ${ }^{1}$ School of Resources and Environmental Studies \\ ${ }^{2}$ Department of Process Engineering and Applied Sciences \\ Dalhousie University, Halifax, Nova Scotia, Canada, B3J 2X4
}

\begin{abstract}
A surface flow constructed wetland consisting of seven cells was used to treat the leachates from a decommissioned landfill. Wetland monitoring was performed by evaluating the treatment efficiency of the landfill leachate and the wetland biological integrity of the wetland. The water quality samples were analyzed for iron, manganese, phosphorus (orthophosphate), $\mathrm{pH}$, dissolved oxygen (DO), nitrogen (ammonia, nitrate, nitrite and TKN), chemical oxygen demand (COD), total suspended solids (TSS) and total dissolved solids (TDS). Aquatic macroinvertebrates were examined using Average Score per Taxon (ASPT) via the Biological Monitoring Working Party (BMWP) biotic index, the Ephemeroptera, Trichoptera, Sphaeriidae and Odonata (ETSD) biotic index, abundance of mayflies and trophic structure. Reductions of 49.66, 66.66, 1.91, 46.37 and 8.33\% were obtained for manganese, orthophosphate, TSS, TDS and COD, respectively. The nitrite, dissolved oxygen and iron concentrations were not in accordance with the water quality guidelines for aquatic life. ASPT, ETSD, percent abundance of mayflies and trophic structure represented moderate to moderately-poor water quality in comparison to a high quality reference site. Iron had most adverse effect on the biological system of the wetland.
\end{abstract}

Key words: Constructed wetland, biological integrity, aquatic macroinvertebrates, biodiversity, trophic structure, mayfly abundance, biotic index

\section{INTRODUCTION}

Wetlands are broadly characterized as saturated land areas supporting aquatic processes as indicated by their poorly drained soils, hydrophilic vegetation and various biological activities that are adapted to a wet environment $^{[1]}$. Wetlands are nature's purifiers which cycle and retain nutrients, pollutants and sediments through unique, naturally adapted mechanisms including, biogeochemical reactions (reduction/ oxidation transformations), phytoremediation (plant uptake of contaminants), bioremediation (microbial degradation) and sedimentation ${ }^{[2,3]}$. They have been called the kidneys of the planet because of the natural filtration processes that occur as water passes through them ${ }^{[4]}$. In terms of both plant and animal wildlife, wetland ecosystems are among the top most productive environments on the planet, sustaining more life than many tropical forests, as well as most good agricultural land ${ }^{[5,6]}$. They provide for the habitat needs of countless species of birds and mammals, as well as fish, amphibians, invertebrates and microbial species that require aquatic environments for breeding, egg development and larval growth ${ }^{[5-7]}$.

Approximately $14 \%$ of the world's wetlands are encountered in Canada where they occupy more than 1.2 million square kilometres ${ }^{[5]}$. Globally, freshwater wetlands, which cover approximately $1 \%$ of the earth's surface, support over $40 \%$ of the world's plant species and $12 \%$ of all animal species ${ }^{[8]}$. In Canada, more than 200 species of birds (including ducks, swans, cranes, gulls, sandpipers, geese and birds of prey) and 50 species of mammals are closely associated with wetlands, for providing breeding and nursery sites, resting areas and refuge from predators. It is estimated that over half of the tens of millions of migratory waterfowl in North America depend on prairie pothole wetland ecosystems alone ${ }^{[5]}$.

Constructed wetlands designed and tailored to take advantage of the passive treatment processes offered by natural wetlands in more controlled, efficient manners are increasingly becoming accepted wastewater treatment alternatives. They offer a more sustainable option for the treatment of wastewater, as they utilize

Corresponding Author: A.E. Ghaly, Professor, Department of Process Engineering and Applied Science, Dalhousie University, Halifax, Nova Scotia, Canada, B3J 2X4, Tel: 902-494-6014 
low technology, have a small ecological footprint and are aesthetically pleasing ${ }^{[9]}$. In this context, to remediate the effects of landfill leachate coming from the Burnside Drive landfill located in Burnside Industrial Park, Dartmouth, Nova Scotia and impacting the natural Wright's Brook ecosystem, a surface flow engineered treatment wetland was designed with the intended purpose of purifying the influent before discharging it back into the brook.

Aquatic macroinvertebrates have been identified as excellent indicators of water quality as they respond rapidly to environmental changes. Their abundance, diversity and short life cycle makes them ideal subjects for the assessment of wetlands ecological conditions ${ }^{[10]}$. They are the most abundant group of organisms in freshwater wetlands and play an important role in the overall functioning of these unique ecosystems as they occupy a central position in wetland food webs ${ }^{[11]}$. Macroinvertebrate monitoring is thus frequently used in environmental quality assessments of aquatic ecosystems ${ }^{[12,13]}$. The basis of most of the metrics involved in water quality bioassessment is focused on the presence or absence of tolerant or intolerant indicator organisms. Intolerant taxa, by definition, are more likely to disappear under impaired conditions; hence their presence indicates good conditions. Tolerant taxa, on the other hand, are capable of surviving in both stressed and pristine systems,

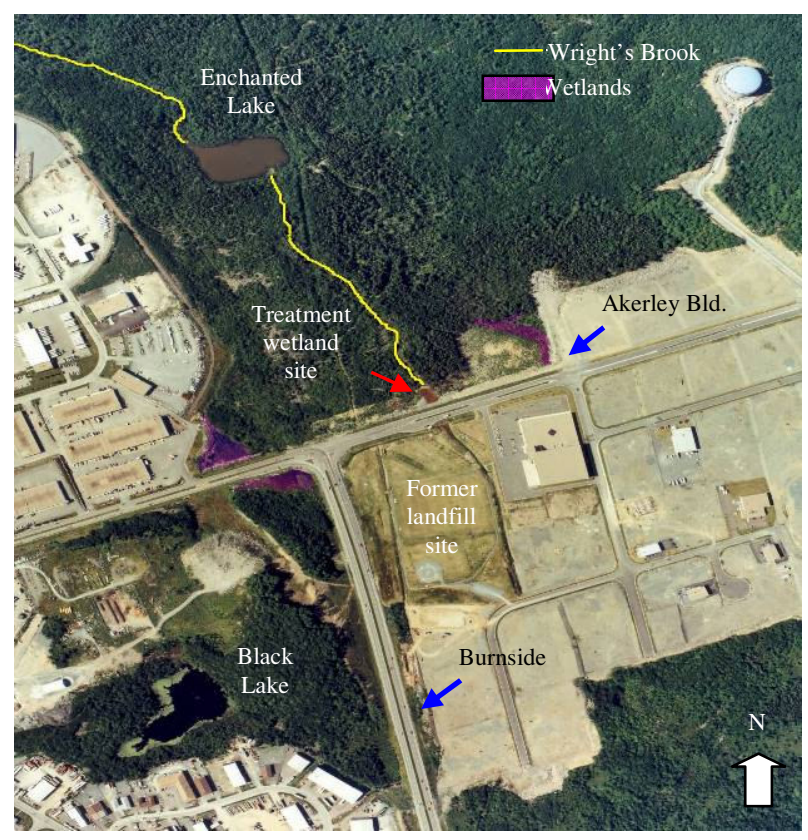

Fig. 1: Aerial photograph of the northern boundary of the Burnside Industrial Park, (scale 1:10000) ${ }^{[15]}$ therefore, the presence of tolerant taxa will not necessarily indicate the presence of poor water quality. According to the USEPA ${ }^{[14]}$, superior metrics are those which evaluate the presence of intolerant taxa.

The purpose of the present study was to use aquatic macroinvertebrate monitoring to : (a) evaluate the efficiency of the Burnside constructed wetland in treating landfill leachate and (b) assess the wetland biological integrity.

\section{BURNSIDE LANDFILL AND CONSTRUCTED WETLAND}

The Burnside Drive landfill (now decommissioned and currently known as the Don Bayer Sports Field) is located near the northern boundary of the Burnside Industrial Park, at the corner of Akerley Boulevard and Burnside Drive (Fig. 1). This 13.4 acre open waste disposal site had accepted municipal, agricultural and industrial wastes, old tires, abandoned cars and demolition wastes (all of which were reportedly burned to reduce volume) from the Dartmouth. The dumpsite was graded, compacted and covered with two feet of soil upon closure, as was common in the day, with no regard to pollution control or aesthetics ${ }^{[16]}$. Since its closure in the 1970's, leachate from the decomposing waste beneath the sports field, as well as stormwater draining from a 55.1 hectare watershed surrounding the

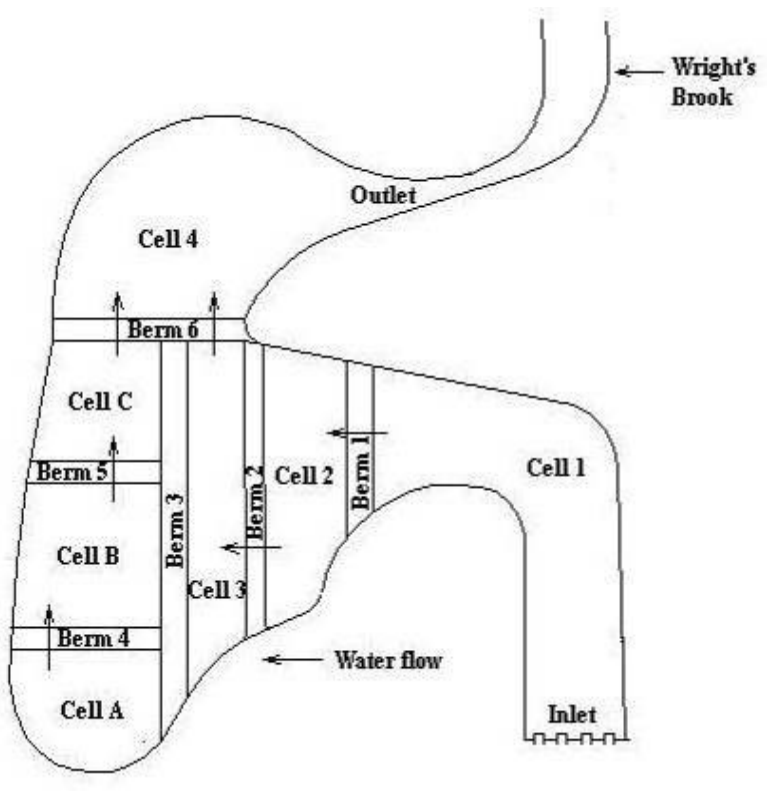

Fig. 2: Burnside treatment wetland diagram 
OnLine J. Biol. Sci., 7 (2): 52-65, 2007

landfill ultimately discharge into Wright's Brook through stormwater ditches located on the western, northern and eastern borders of the sports field. Wright's Brook traverses $4.6 \mathrm{~km}$, passing through Enchanted and Flat lakes before discharging into the Bedford Basin of the Halifax Harbour. Water quality analyses of the stormwater ditches indicated that the leachate wastewater contained elevated levels of iron, manganese, ammonia and suspended solids. This wastewater discharge has had visible adverse effects on Wright's Brook and the associated ecosystems.

To address the problem, a seven celled surface flow engineered treatment wetland (approximately $5000 \mathrm{~m}^{2}$ in area) was constructed in the late fall of 2001 and spring of 2002 (Fig. 2). The wetland consists of a deep-water (greater than $1 \mathrm{~m}$ ) system separated by shallow interior earth berms of $2 \mathrm{~m}$ width, which were constructed in the marshy area receiving the leachate wastewaters. The wetland was designed to curve in a kidney shape in order to increase the length to width ratio to about 5 to 1 . The first wetland cell was deeper than the others (approximately $1.5 \mathrm{~m}$ ) in order to facilitate the settling and accumulation of suspended solids. The till of the area was found to support 15-25\% silt/clay with dense to very dense consistency and a permeability of $10^{-4}$ to $10^{-6} \mathrm{~cm} \mathrm{sec}^{-1[17]}$. Subsequently, it was concluded that compaction of the area substrates would provide adequate lining for the site. The natural gravitational flow facilitated by the site topography negated the need for any mechanical infrastructure such as pumps.

\section{WATER SAMPLING AND ANALYSES}

On July 21, 2003 water quality samples were collected from Cell 1 and the outlet and analyzed for iron, manganese, phosphorus (orthophosphate), $\mathrm{pH}$, dissolved oxygen (DO), nitrogen (ammonia, nitrate, nitrite and TKN), chemical oxygen demand (COD), total suspended solids (TSS) and total dissolved solids (TDS). Nitrogen, pH, COD, TSS, TDS and orthophosphate were analyzed in the Biotechnology Laboratory, Dalhousie University according to the procedures described in Standard Methods for the Examination of Water and Wastewater ${ }^{[18]}$. Iron, manganese and orthophosphate were analyzed in the Mineral Engineering Laboratory at Dalhousie University. Iron and manganese concentrations were determined using Flame Atomic Absorption (Varian SpectrAA, Model No. 55B, Varian Inc., Mulgrave, Victoria, Australia) with a detection limit of $1 \mathrm{ppm}$. The accuracy of the analysis was verified using reference standards from CANMET Mining and Mineral Sciences
Laboratories (CANMET-MMSL).

\section{AQUATIC MACROINVERTEBRATE SAMPLING AND ANALYSES}

To be effectively assessed, the data (i.e., diversity values, dominance values, etc.) from the treatment site had to be compared to the data collected from a healthy, local reference site. The reference site for the Burnside treatment wetland study was selected by examining wetland inventories ${ }^{[19]}$. Classifications were based on factors such as dominant vegetation, location, the presence, depth and permanence of surface water, wetland size, topographic and hydrologic surrounding habitat, proportions and interspersion of cover, water and vegetation and water chemistry. Freshwater systems are scored values between 36 and 108, with values greater than 60 perceived as having high biodiversity, high habitat value and overall ecological health $^{[19]}$. As a result of its fitting classification and close location (approximately $25 \mathrm{~km}$ from the Burnside site) marsh A-8 in the Waverly Game Sanctuary, was selected as the reference site for the biological integrity assessment. In July 2003, macroinvertebrate samples were taken from the reference wetland, as well as from both Cell 1 and the outlet of the treatment wetland (Fig. 3) using a $0.6 \mathrm{~mm}$ mesh size sweep net. Samples were gathered at two locations in the constructed wetland in an attempt to gauge any differences in the biological integrity of the macroinvertebrate populations between the most contaminated area of the system and the most purified area of the system.

Each dipnet sample contained a large number of organisms. As is the case with most macroinvertebrate sampling schemes, complete census would have been unreasonable. Consequently, the organisms were subsampled to 100 organisms. The contents of the sweep net were divided as equally as possible into five $1 \mathrm{~L}$ sample jars filled with approximately $750 \mathrm{~mL}$ of a mixture of alcohol and water (50/50), which killed and preserved the captured organisms. This was repeated for each of the three sampling sites. The subsample was obtained by randomly selecting one of the five jars from each sample site. Using the turkey baster, samples were drawn from the jars and placed in Petri dishes for examination until 100 organisms were obtained. If the jar yielded less than 100 organisms, another jar was randomly selected from the same sample obtained from that site location and sampled until 100 organisms for the site were retrieved as recommended by the USEPA $^{[14]}$. In total, sweeps of each sample site yielded 300 macroinvertebrates; 100 for each sample site.

Using the Freshwater Macroinvertebrates of 
OnLine J. Biol. Sci., $x(x): x x-x x, 2007$

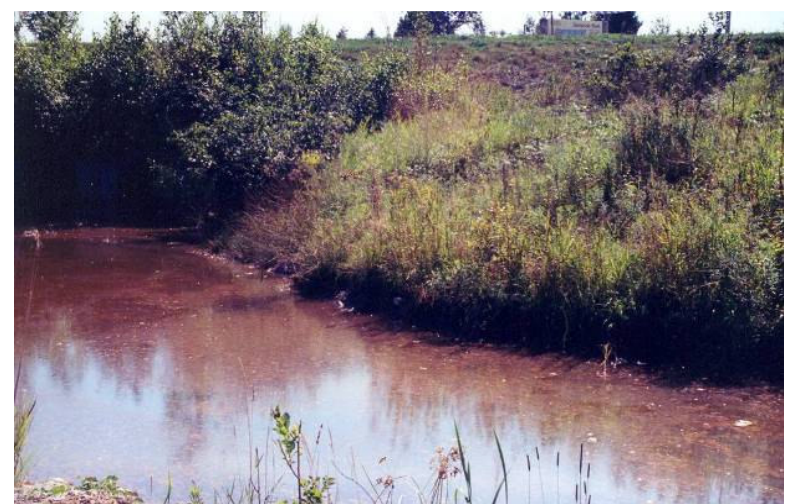

(a) Cell 1

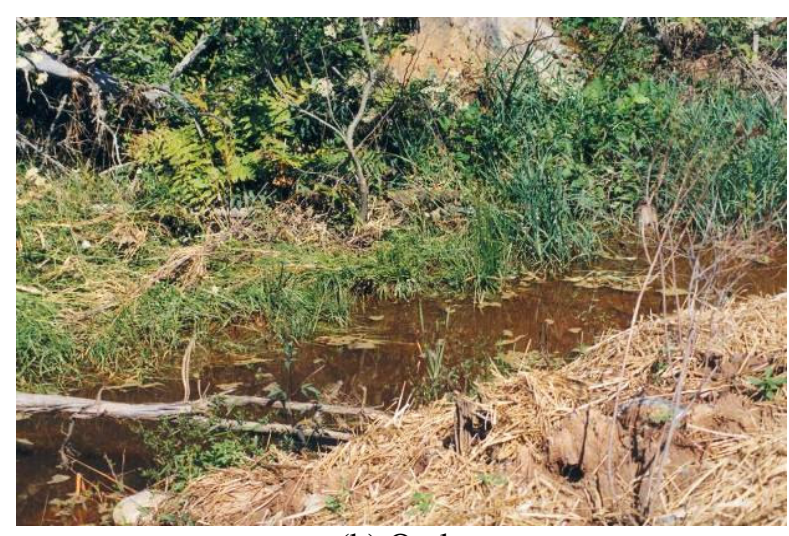

(b) Outlet

Fig. 3: Sampling locations for aquatic macroinvertebrates in treatment wetland

Northeastern North America aquatic macroinvertebrate identification guide ${ }^{[20]}$ as well as a dissecting microscope, the insects were identified to the family level.

The aquatic macroinvertebrate samples were examined as indicators of water quality using several specific water quality metrics: (a) Average Score per Taxon (ASPT) via the Biological Monitoring Working Party (BMWP) biotic index, (b) the Ephemeroptera, Trichoptera, Sphaeriidae and Odonata (ETSD) biotic index, (c) percent abundance of mayflies and trophic structure (Table 1).

ASPT index: The Average Score Per Taxon (ASPT) represents the average tolerance score of all taxa within the community. The ASPT is calculated by dividing the family level-based Biological Monitoring Working Party (BMWP) score by the number of indicator families present in the sample. The biotic index described by $\mathrm{Kirsch}^{[21]}$ and Mandaville ${ }^{[22]}$ is devised to limit the taxonomic requirement of many biotic indices to identify organisms to species level which requires a rare kind of expertise. The BMWP assigns pollution tolerance scores between 1 and 10 to all indicator organisms present at the family level. The greater their tolerance towards pollution, the lower their BMWP score. Individual scores are then tabulated to get a total BMWP score (Table 2). The water quality assessment generally associated with the ASPT scores are listed in Table 3. ASPT scores were calculated for each of the macroinvertebrate samples taken from each of the study sites.

ETSD index: The ETSD biotic index summarizes the taxa richness of the listed taxonomic groups. The intolerant taxa are considered highly pollution-sensitive in wetland waters, hence greater abundances of these groups typically indicate greater site health. Although this index was developed for use with species-level identification, Mandaville ${ }^{[22]}$ indicated that it is also valid for use with family level identifications. The ESTD abundance was calculated as follows:

$$
\text { ETSD abundance }=\frac{\text { Total No. of ETSD families }}{\text { Total No. of families }} \times 100
$$

Mayflies abundance: Although mayflies (Ephemeroptera) are a component of the ETSD Biotic Index, it was important to examine the abundance of this indicator group on its own, as mayflies are specifically sensitive to the Burnside treatment wetland site contaminants of concern (ammonia and metals). They are also sensitive to low dissolved oxygen (less than $5 \mathrm{ppm}$ ), chlorine, pesticides and acidity. The mayfly abundance was calculated as follows:

$$
\text { Mayfly abundance }=\frac{\text { Total No. of mayfly families }}{\text { Total No. of families }} \times 100
$$

Trophic structure: The term 'trophic structure' relates to the feeding habits of the macroinvertebrates. Balance shifts in functional feeding groups (i.e., scrapers, shredders, collectors, predators) can be indicative of specific pollution-related stress. The proportions of each feeding group are expected to fluctuate to unnaturally occurring proportions in unhealthy wetland systems. Increased ratios of predators to scrapers, shredders and collectors can be indicative of heavy metal pollution, whereas decreased ratios of predators to scrapers, shredders and collectors indicative of organic pollution and low dissolved oxygen ${ }^{[7,14]}$.

The macroinvertebrate trophic structure was examined with these specific pollution indicators in 
OnLine J. Biol. Sci., 7 (2): 52-65, 2007

Table 1: Selected aquatic macroinvertebrate metrics of water quality ${ }^{[7,14,21,22]}$

\begin{tabular}{ll}
\hline Metric & Premise \\
\hline ASPT via BMWP biotic index & $\begin{array}{l}\text { The Average Score per Taxon (ASPT) represents the average tolerance score of all taxa within the } \\
\text { community and is calculate by dividing the BMWP (Biological Monitoring Working Party) score by } \\
\text { the number of families in the sample. }\end{array}$ \\
ETSD & $\begin{array}{l}\text { Measure abundance of pollution-sensitive groups in wetlands, specifically Ephemeroptera E (mayflies), } \\
\text { Trichoptera T (caddisflies), Sphaeriidae S (fingernail clams) and Odonata D (dragonflies/damselflies). } \\
\text { These intolerant taxa are sensitive to pollution, hence greater abundances of these families indicated } \\
\text { greater site health. }\end{array}$ \\
Mayfly abundance & Mayflies sensitive to ammonia, metals, low dissolved oxygen, chlorine, pesticides and acidity \\
Trophic structure & Altered trophic structures are indicative of specific pollutant loading (i.e. increased ratio of predators to \\
& others indicative of heavy metal pollution, decreased ratios indicative of organic pollution and low DO)
\end{tabular}

Table 2: Pollution sensitivity grades for aquatic macroinvertebrate families ${ }^{[21-23]}$

\begin{tabular}{|c|c|c|c|c|c|c|c|c|}
\hline \multirow[b]{2}{*}{ Family } & \multicolumn{2}{|c|}{ Grade } & \multirow[b]{2}{*}{ Family } & \multicolumn{2}{|c|}{ Grade } & \multirow[b]{2}{*}{ Family } & \multicolumn{2}{|c|}{ Grade } \\
\hline & $\mathrm{N}$ & $\mathrm{B}$ & & $\mathrm{N}$ & $\mathrm{B}$ & & $\mathrm{N}$ & $\mathrm{B}$ \\
\hline Acariformes & 6 & - & Erpobdellidae & 3 & 3 & Oedicerotidae & 4 & - \\
\hline Aeolosomatidae & 2 & - & Gammaridae & 4 & 6 & Oligochaeta & 2 & 1 \\
\hline Aeshnidae & 6 & 8 & Gerridae & 5 & 5 & Peltoperlidae & 9 & - \\
\hline Agrionidae & 4 & 8 & Glossiphoniidae & 3 & 3 & Perlidae & 8 & 10 \\
\hline Ancylidae & 4 & 6 & Glossosomatidae & 10 & - & Perlodidae & 8 & 10 \\
\hline Anthomyiidae & 4 & - & Gomphidae & 6 & 8 & Philopotamidae & 7 & 8 \\
\hline Anthuridae & 4 & - & Gordiidae & 8 & 10 & Phryganeidae & 7 & - \\
\hline Asellidae & 2 & 3 & Gyrinidae & 5 & 5 & Physidae & 2 & 3 \\
\hline Arctiidae & 5 & - & Haliplidae & 5 & 5 & Piscicolidae & 5 & 4 \\
\hline Arrenuridae & 4 & - & Haplotaxidae & 1 & 1 & Planariidae & 4 & 5 \\
\hline Astacidae & 4 & 8 & Helicopsychidae & 7 & - & Planorbidae & 3 & 3 \\
\hline Athericidae & 6 & - & Helodidae & 5 & 5 & Platyhelminthidae & 6 & - \\
\hline Atractideidae & 4 & - & Heptageniidae & 7 & 10 & Pleidae & 5 & 5 \\
\hline Baetidae & 5 & 4 & Hirudinea & 0 & - & Pleuroceridae & 4 & - \\
\hline Baetiscidae & 6 & - & Hyalellidae & 2 & - & Polycentropodidae & 4 & 7 \\
\hline Belostomatidae & 5 & - & Hydridae & 5 & - & Polychaeta & $4 ?$ & - \\
\hline Blephariceridae & 10 & - & Hydrobiidae & 4 & 3 & Polymetarcyidae & 8 & - \\
\hline Branchiobdellidae & 4 & - & Hydrometridae & 5 & 5 & Potamanthidae & 6 & 10 \\
\hline Brachycentridae & 9 & 10 & Hydrophilidae & 5 & 5 & Psephenidae & 6 & - \\
\hline Caenidae & 5 & 7 & Hydropsychidae & 6 & 5 & Psychodidae & 8 & 8 \\
\hline Calopterygidae & 4 & - & Hydroptilidae & 5 & 6 & Psychomyiidae & 8 & 8 \\
\hline Capniidae & 8 & 10 & Hygrobiidae & 5 & 5 & Pteronarcidae & 10 & - \\
\hline Ceratopogonidae & 4 & - & Idoteidae & 5 & - & Ptychopteridae & 1 & - \\
\hline Chaoboridae & 2 & - & Isotomidae & 5 & - & Pyralidae & 5 & - \\
\hline Chironomidae & 1 & 2 & Lebertiidae & 4 & - & Rhyacophilidae & 9 & - \\
\hline Chloroperlidae & 10 & 10 & Lepidostomatidae & - & - & Sabellidae & 4 & - \\
\hline Chrysomelidae & 5 & 5 & Leptoceridae & 6 & 10 & Sialidae & 6 & 4 \\
\hline Coenagrionidae & 2 & 6 & Leptophlebiidae & 7 & 10 & Simuliidae & 5 & - \\
\hline Collembola & $5 ?$ & - & Lestidae & 1 & - & Siphlonuridae & 8 & 10 \\
\hline Corbiculidae & 4 & - & Leuctridae & 10 & 10 & Sphaeriidae & 4 & 3 \\
\hline Corduliidae & 7 & 8 & Libellulidae & 8 & 8 & Spurchonidae & 4 & - \\
\hline Cordulegasteridae & 7 & 8 & Limnephilidae & 7 & 7 & Sisyridae & 5 & - \\
\hline Corixidae & 5 & 5 & Limnesidae & 4 & - & Tabanidae & 5 & - \\
\hline Corydalidae & 6 & - & Limnocharidae & 4 & - & Taeniopterygidae & 8 & 10 \\
\hline Culicidae & 1 & - & Lumbriculidae & 2 & 1 & Talitridae & 2 & - \\
\hline Dixidae & 10 & - & Lymnaeidae & 4 & 3 & Thiaridae & 6 & - \\
\hline Dolichopodidae & 6 & - & Mesoveliidae & 5 & 5 & Tipulidae & 7 & 5 \\
\hline Dreissenidae & 2 & - & Mideopsidae & 4 & - & Tricorythidae & 6 & - \\
\hline Dryopidae & 5 & 5 & Molannidae & 4 & 10 & Tubificidae & 1 & 1 \\
\hline Dytiscidae & 5 & 5 & Muscidae & 4 & - & Tyrellidae & 4 & - \\
\hline Elmidae & 5 & 5 & Naididae & 3 & 1 & Unionidae & 4 & 6 \\
\hline Empididae & 4 & - & Nemouridae & 8 & 7 & Unionicolidae & 4 & - \\
\hline Enchytreidae & 1 & 1 & Nepidae & 5 & 5 & Valvatidae & 2 & 3 \\
\hline Ephemerellidae & 10 & 10 & Nepticulidae & 5 & - & Veliidae & 5 & - \\
\hline Ephemeridae & 8 & 10 & Notonectidae & 5 & 5 & Viviparidae & 4 & 6 \\
\hline Ephydridae & 4 & - & Odontoceridae & 10 & 10 & & & \\
\hline
\end{tabular}

$\mathrm{N}=$ No. of families occurring in North America; $\mathrm{B}=\mathrm{BWMP}$ Score 
OnLine J. Biol. Sci., 7 (2): 52-65, 2007

Table 3: Average score per taxon ${ }^{[22]}$

\begin{tabular}{ll}
\hline ASTP value & Water quality \\
\hline$>6.0$ & Excellent water quality \\
$5.5-6.0$ & Very good water quality \\
$5.0-5.5$ & Good water quality \\
$4.5-5.0$ & Moderate water quality \\
$4.0-4.5$ & Moderately-poor water quality \\
$<4.0$ & Poor water quality \\
\hline
\end{tabular}

mind and calculated as follows:

Proportional abundance $=$

$\frac{\text { Total No. of individuals per feeding group }}{} \times 100$

Total No. of individuals

The macroinvertebrate samples collected were also assessed for family diversity using the Shannon-Weiner index, which is a measure of the proportional abundance of each aquatic macroinvertebrate family present at one location ${ }^{[24,25]}$. The Shannon-Weiner index was calculated as follows:

$$
H=-\Sigma\left[P_{i}\left(\ln P_{i}\right)\right]
$$

Where:

$\mathrm{H}$ = Shannon-Weiner diversity index.

$\mathrm{P}_{\mathrm{i}}=$ Proportional abundance of a given family (i). follows:

The proportional abundance $\left(\mathrm{P}_{\mathrm{i}}\right)$ was calculated as

$$
\mathrm{P}_{\mathrm{i}}=\mathrm{n}_{\mathrm{i}} / \mathrm{N}
$$

Where:

$\mathrm{n}_{\mathrm{i}} \quad=$ The number of individuals of a given family (i).

$\mathrm{N}=$ The total number of individuals of all families.

The higher the Shannon-Weiner index, the more diverse the system is implied to be in terms of family numbers. A site supporting high macroinvertebrate diversity similar to that of a pristine, natural wetland site is said to possess biological integrity ${ }^{[14,22]}$. The variance in diversity was calculated as follows:

$\mathrm{H}_{\mathrm{var}}=\mathrm{N}^{-1}\left\{\Sigma \mathrm{p}_{\mathrm{i}}\left(\ln \mathrm{P}_{\mathrm{i}}\right)^{2}-\left[\Sigma \mathrm{p}_{\mathrm{i}}\left(\ln \mathrm{P}_{\mathrm{i}}\right)\right]^{2}\right\}-\left\{\left(2 \mathrm{~N}^{2}\right)^{-1}\{\mathrm{~S}-1]\right\}$

Where:

$\mathrm{H}_{\mathrm{var}}=$ Variance in diversity.

$\mathrm{S}=$ Total number of families.

The values obtained from the reference site and from Cell 1 and the outlet of the treatment wetland were compared to each other using parametric t-test statistics (t) as follows:

$$
\mathrm{t}=\frac{\left[\mathrm{H}_{\text {(ref site) }}-\mathrm{H}_{\text {(treatment site) }}\right]}{\left[\mathrm{H}_{\text {var (ref site) }}+\mathrm{H}_{\text {var (rreatment site) }}\right]^{0.5}}
$$

The accuracy of the tests was gauged by calculating the degrees of freedom (df) existing for the tests as follows ${ }^{[24]}$ :

$$
\mathrm{df}=\frac{\left[\mathrm{H}_{\text {var(ree site) }}+\mathrm{H}_{\text {var(treatment site) }}\right]}{\left[\mathrm{H}_{\text {var(ree site) }}\right]^{2} / \mathrm{N}_{\text {(ref site) }}+\left[\mathrm{H}_{\text {var(rreatment site) }}\right]^{2} / \mathrm{N}_{\text {(treatment site) }}}
$$

The macroinvertebrate populations were further assessed on the family level through the determination of heterogenity. The assumption here is that sites having high dominance figures (i.e., top 3 families dominate $95 \%$ of sample site), are not as biologically healthy as those sites supporting a more balanced distribution of organisms ${ }^{[14,22]}$. The heterogeneity was calculated as follows:

Heterogenity $=\frac{\text { Abundance of the top } 3 \text { families }}{\text { Total No. of families }} \times 100$

\section{RESULTS AND DISCUSSION}

The water quality and biological integrity assessment of the aquatic macroinvertebrate community of the reference and constructed wetlands (Cell 1 and Outlet) are presented in Table 4 and 5. The population richness, heterogeneity and trophic structure are shown in Fig. 4-6.

Water quality: There are no water quality guidelines reported by the Canadian Council for Ministers of Environment (CCME) for the protection of aquatic life for manganese, orthophosphate, TSS, TDS, TKN and $\mathrm{COD}^{[26]}$. On July $21 \mathrm{st} 2003$, reductions of $49.66,66.66$, $1.91,46.37$ and $8.33 \%$ were obtained for manganese, orthophosphate, TSS, TDS and COD respectively as water flowed through the Burnside constructed wetland. There was an increase of $52.94 \%$ in the TKN concentration between Cell 1 and the outlet. Although a reduction of $67.36 \%$ in iron was achieved, the outlet concentration of $2.51 \mathrm{mg} \mathrm{L}^{-1}$ was higher than the 0.3 $\mathrm{mg} \mathrm{L}^{-1}$ guideline established by $\mathrm{CCME}^{[26]}$. The nitrate concentration was below the water quality guideline for the protection of aquatic life of $13 \mathrm{mg} \mathrm{L}^{-1}$ established by $\mathrm{CCME}^{[26]}$. The nitrite concentration exceeded the guideline concentration of $0.06 \mathrm{mg} \mathrm{L}^{-1}$ for protection of aquatic life. The high nitrite levels obtained in the 
OnLine J. Biol. Sci., 7 (2): 52-65, 2007

outlet may be correlated with the stagnation observed in the site that day as nitrite can persist in waters which suffer from oxygen depletion. The dissolved oxygen obtained at the site was below the minimum guideline of $5.5 \mathrm{mg} \mathrm{L}^{-1}$ established by the CCME for the protection of aquatic life ${ }^{[26]}$. Generally, ammonium decreased by $67 \%$ and was not detected in some of the samples. $\mathrm{NH}_{4}$ is fairly harmless whereas $\mathrm{NH}_{3}$ can be lethal at high level. No $\mathrm{NH}_{3}$ was produced as the $\mathrm{pH}$ was below 8.5. The $\mathrm{pH}$ value was in the range established by CCME for freshwater (6.5 to 9.0$)^{[26]}$.

Chemical analyses of water quality provide useful information about the presence of contaminants in the waters sampled at the treatment site at the time they were taken. However, chemical analyses can be a poor indicator of long-term environmental variations causing cumulative or chronic effects. The biological effect of many chemicals is often much longer lasting than the pollution event itself. Chemical analyses cannot detect degradation from non-chemical sources as competition from introduced species ${ }^{[27]}$. These types of analyses are also of limited value in identifying less tangible indicators of declining system health such as habitat degradation. Aquatic organisms on the other hand must live for weeks or months in water, tolerating every fluctuation and variable the system provides, hence complementing traditional water quality analysis with biomonitoring techniques can provide useful integrative measures of water quality ${ }^{[7,28,29]}$. Generally, bioindicators used in this water quality monitoring technique are aquatic macroinvertebrates, fish, and/or plankton.

The benefits of monitoring this group include: (a) since aquatic macroinvertebrates are a highly diverse group, consisting of more than 4000 species in Canada, (b) macroinvertebrates are typically the simplest and cheapest bioindicators to measure requiring few people, inexpensive gear and having minimal impact on the system being sampled ${ }^{[7,23]}$, they are naturally excellent indicators of biological condition, especially biodiversity $^{[22]}$, (c) macroinvertebrates are essential components of wetland food webs ${ }^{[14]}$, (d) unlike fish which may not even be present in wetland sites, aquatic macroinvertebrates are abundant in wetland systemsand are small enough to be easily collected, yet unlike plankton, are large enough to be easily identified $^{[7,21,23,28]}$, (e) due to their limited mobilities and the fact that most species complete their life cycles in a relatively small area, aquatic macroinvertebrates are particularly well-suited for assessing site-specific health $^{[14]}$ and (f) aquatic macroinvertebrates are excellent indicators of system health as they are known
Table 4: Water quality parameters of the Burnside constructed wetland

\begin{tabular}{|c|c|c|c|}
\hline Parameters & Cell 2 & Outlet & Reduction (\%) \\
\hline $\mathrm{Fe}\left(\mathrm{mg} \mathrm{L}^{-1}\right)$ & 7.69 & 2.51 & 67.36 \\
\hline $\operatorname{Mn}\left(\mathrm{mg} \mathrm{L}^{-1}\right)$ & 1.45 & 0.73 & 49.66 \\
\hline $\mathrm{NO}_{2}\left(\mathrm{mg} \mathrm{L}^{-1}\right)$ & 0.09 & 0.59 & $(555.55)$ \\
\hline $\mathrm{NO}_{3}\left(\mathrm{mg} \mathrm{L}^{-1}\right)$ & 5.73 & 4.28 & 25.31 \\
\hline $\mathrm{NH}_{4}\left(\mathrm{mg} \mathrm{L}^{-1}\right)$ & 3.00 & 0.25 & 91.67 \\
\hline $\mathrm{TKN}\left(\mathrm{mg} \mathrm{L}^{-1}\right)$ & 4.25 & 6.50 & $(52.94)$ \\
\hline $\mathrm{PO}_{4}\left(\mathrm{mg} \mathrm{L}^{-1}\right)$ & 0.03 & 0.01 & 66.66 \\
\hline $\operatorname{TSS}\left(\mathrm{mg} \mathrm{L}^{-1}\right)$ & 523.00 & 513.00 & 1.91 \\
\hline $\operatorname{TDS}\left(\mathrm{mg} \mathrm{L}^{-1}\right)$ & 509.00 & 273.00 & 46.37 \\
\hline $\operatorname{COD}\left(\mathrm{mg} \mathrm{L}^{-1}\right)$ & 1092.00 & 1001.00 & 8.33 \\
\hline $\mathrm{DO}\left(\mathrm{mg} \mathrm{L}^{-1}\right)$ & 4.10 & 4.40 & (7.32) \\
\hline $\mathrm{pH}$ & 7.20 & 7.20 & 0.00 \\
\hline
\end{tabular}

()$=$ increase

to respond with a range of sensitivities to many kinds of stressors $^{[14]}$. Decreased species diversity, heterogeneity and skewed trophic structure are excellent indicators of an unhealthy system undergoing stress. However, more specific metrics exist which are indicative of the cause of that stress such as increased turbidity, nutrient and metal identification of most macroinvertebrate taxa, as the immature stages of macroinvertebrates present in spring can be quite difficult to identify. In addition, one-time phosphorus loading (a likely consequence of seasonal greenspace fertilizing) occurred in early spring, resulting in hyper-eutrophic conditions temporarily triggering prolific algal growth. Had the sampling taken place in the spring, the results would not have been representative of the conditions occurring in the site during the remainder of the summer and autumn. For example, dragonflies (Leucorrhinia, Libellula), caddisflies (Triaenodes, Oecetis), chironomids (Tanytarsus, Procladius) and fingernail clams (Sphaeriidae) are all intolerant of phosphorus ranging from 0.015 to $1.38 \mathrm{mg} \mathrm{L}^{-1}$.

All of these taxa, which are excellent indicators of good water quality, may have been absent from samples in spring, but present in the site once P-levels abided.

BMWP and ASPT: The Biological Monitoring Workshop Party (BMWP) score and corresponding Average Score per Taxon (ASPT) for the reference wetland site was 107 and 5.94, respectively. This score is indicative of very good water quality. The BMWP and corresponding ASPT score for Cell 1 of the treatment wetland site was 34 and 4.86, respectively. This score is indicative of moderate water quality. Finally, the BMWP and corresponding ASPT score for the outlet of the treatment wetland site was 30 and 4.29, respectively. 
OnLine J. Biol. Sci., 7 (2): 52-65, 2007

Table 5: Biological integrity assessment of wetland aquatic macroinvertebrates

\begin{tabular}{llll}
\hline Metric & Reference Site & Cell 1 & Outlet \\
\hline ASTP via BMWP biotic & 5.94 & 4.86 & 4.29 \\
ESTD biotic index & $45.45 \%$ & $7.69 \%$ & $0 \%$ \\
Mayfly abundance & $13.64 \%$ & $0 \%$ & $0 \%$ \\
Trophic structure (Scrapers: Shredders: Collectors: Predators) & $2 \% 2 \% 77 \% 13 \%$ & $0 \% 2 \% 96 \% 2 \%$ & $0 \% 0 \% 97 \% 3 \%$ \\
Population Richness & 22 & 13 & 16 \\
Population Diversity (H) & 1.115 & 0.882 & 0.675 \\
Variance (Hvar) & 0.028 & 0.022 & 0.023 \\
Heterogeneity (Dominance) & $58 \%$ & $64 \%$ & $67 \%$ \\
\hline
\end{tabular}

Statistic : Ref. to Cell $1=0.690$, Ref. to Outlet $=1.595$, Cell 1 to Outlet $=0.968$, Degrees of Freedom (df): Ref. to Cell $1=197$, Ref. To Outlet $=$ 198 , Cell 1 to Outlet $=200$, Critical $\underline{t}$ values $:(\propto 20.05)=1.96$ and 1.98

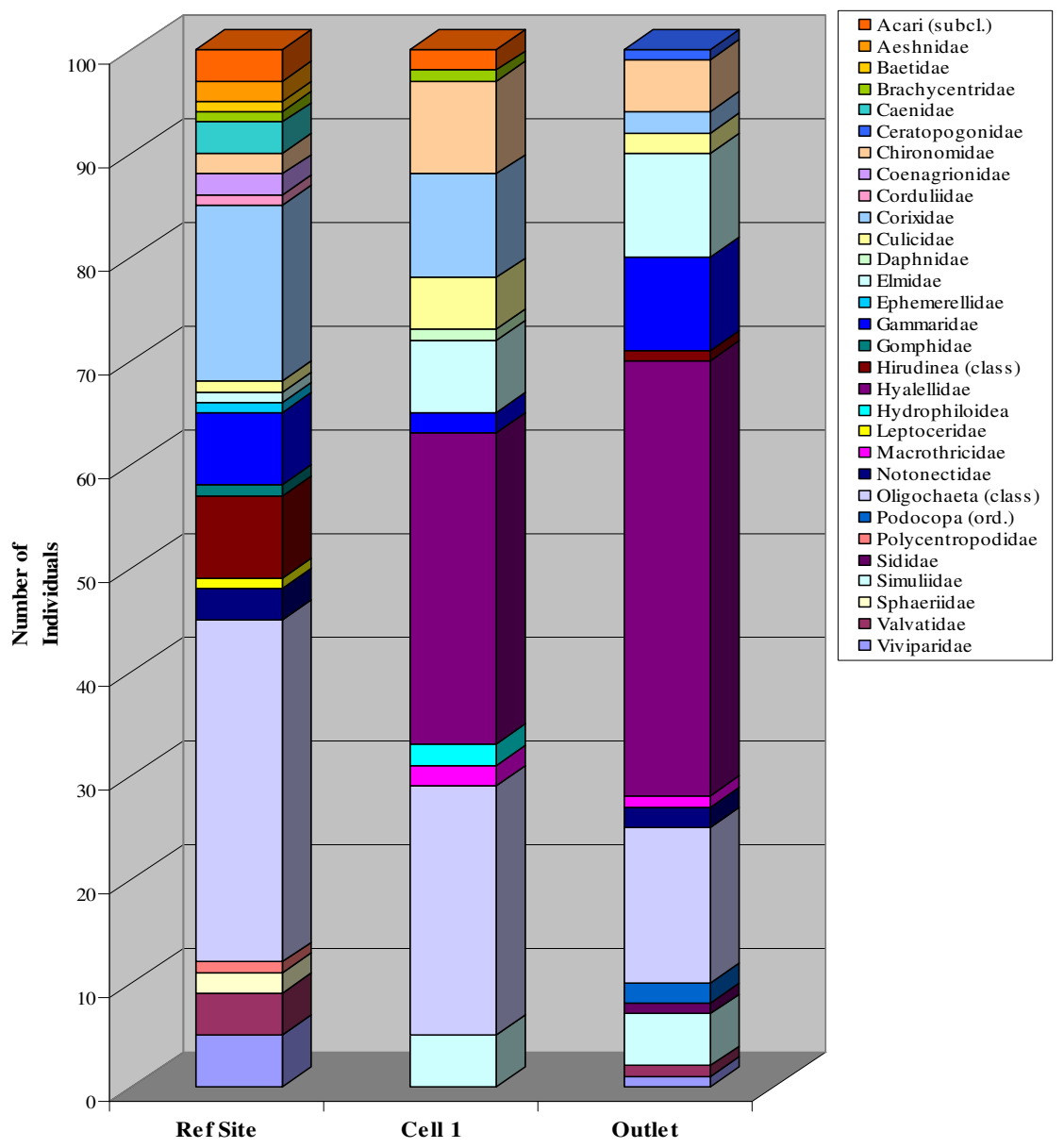

Fig. 4: Aquatic macroinvertebrate richness

This score is indicative of moderately-poor water quality $^{[22]}$. It was hoped that the scores of the inlet and outlet would be significantly different, indicating improved water quality and that the scores of the outlet would be somewhat similar to that of the reference site, indicating the effectiveness of the treatment wetland. The results showed that the treatment site supported less pollution sensitive taxa than did the reference site and the outlet supported less pollution sensitive taxa than Cell 1, which would indicate that the water quality is actually degrading as it flows through the system. This index was designed to be used as a broad indicator of water quality and is limited in its ability to pinpoint any potential causes of the observed degradation ${ }^{[21,22]}$.

ESTD: ETSD families are particularly sensitive to pollution and are typically only found in abundance in waterbodies supporting high water quality. 
OnLine J. Biol. Sci., 7 (2): 52-65, 2007

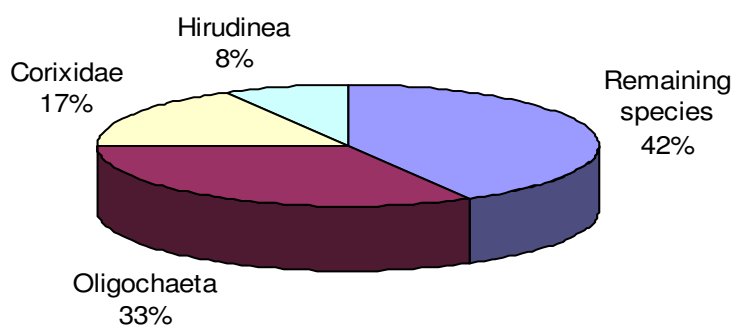

(a) Reference site

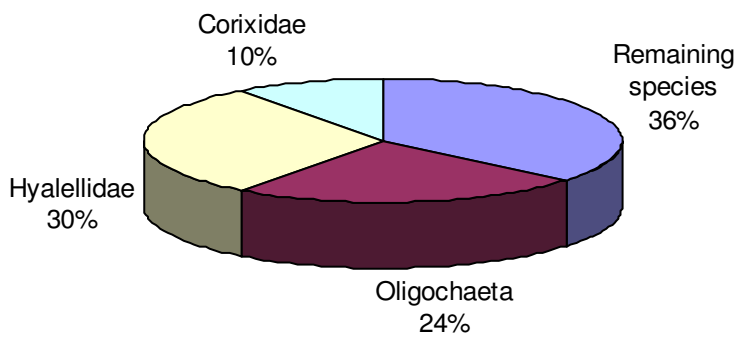

(b) Cell 1

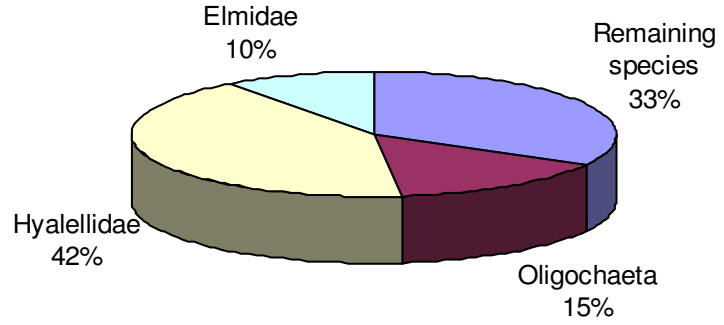

(c) Outlet

Fig. 5: Abundance of top three aquatic macroinvertebrate taxa

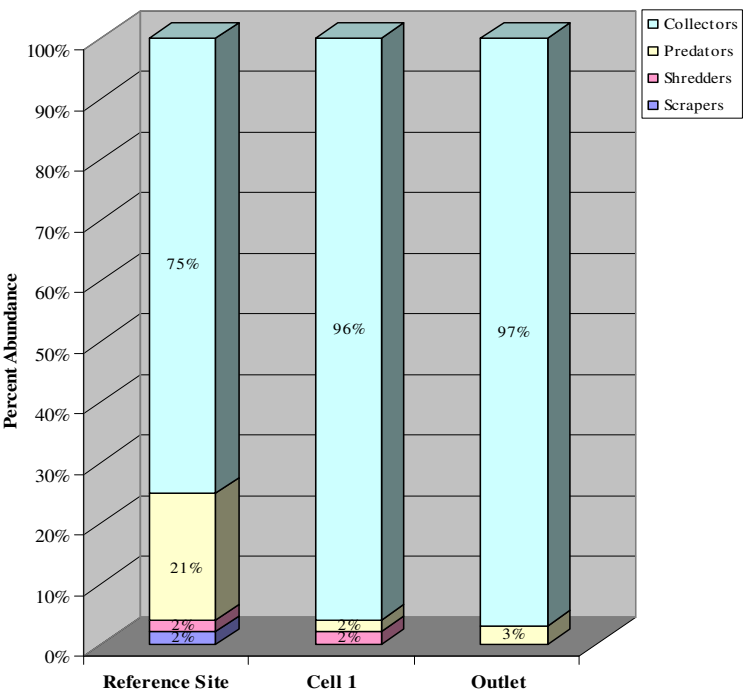

Fig. 6: Trophic structure of aquatic macroinvertebrates
It was hoped that percent abundance of Ephemeroptera (mayflies), Trichoptera (caddisflies), Sphaeriidae (fingernail clams) and Odonata (dragonflies and damselflies) (ESTD) families in Cell 1 would differ significantly from the outlet, indicating improving water quality as the leachate wastewaters flow through the site and that the percent abundance of ESTD families in the outlet and reference site would be similar thereby demonstrating that the treatment wetland was capable of remediating the wastewaters to a quality similar to that of a natural, pristine wetland ecosystem. However, neither of these scenarios were evident from the results. The ETSD families in the reference wetland site accounted for $45.45 \%$ of the site's families. Conversely, ETSD families only accounted for $7.69 \%$ of the families sampled in Cell 1 and $0 \%$ of the families sampled in the outlet of the treatment wetland. The fact that no ETSD families were sampled in the outlet shows not only that the water quality is very poor, but that it is actually not improving as it moves through the site, which concurs with the ASPT results.

The potential causes of the results can be explored by examining the specific sensitivities and requirements of the individual ETSD families. Trichoptera larvae are silk producing creatures that create portable cases used as retreats similar to that of snails. Using their silk, they attach themselves to solid, unmoving objects; usually rocks. Cell 1 and the outlet of the treatment wetland had observably high levels of precipitated iron which densely coats the substrates and other objects such as rocks. This slimy coating makes it extremely difficult for larvae to securely attach themselves to anything. In addition, many Trichoptera larvae breathe through sensitive gills which are easily damaged and clogged by particulate matter. As a result, many species of this family were unable to withstand turbid conditions. The presence of the iron particulate in the treatment wetland has caused the systems waters to be exceedingly turbid. Hence, the high abundance of the precipitated iron in the treatment wetland is a likely cause of their absence ${ }^{[20,30]}$.

Sphaeriidae are small clams with thin, fragile shells. They move slowly along bottom sediments by revealing a foot through a small opening, which makes contact with the substrate. They feed by using their specially adapted large gills to filter organic particles from the water. An overabundance of non-organic particles such as those associated with siltation or the iron particulate can actually harm their feeding mechanisms. In addition, unstable substrates coated with overabundant fine particulates hinder their ability to attach and move along the bottom sediments. Hence 
the presence of particulate matter is a likely cause of their absence in the treatment wetland ${ }^{[20,30]}$.

Odonata larvae are a diverse group of predatory insects which exist both within the substrates and water column. Like Trichoptera and Sphaeriidae, Odonata breathe through gills. However, most species have special adaptations which protect the gills from damage associated with turbid conditions. Some can even live without their gills if damaged, relying on diffusion through the skin for their source of oxygen. Unfortunately, the presence of abundant particulate matter affects them in a different way. Odonata are visual predators, hence in turbid waters, their ability to capture food to sustain themselves is extremely compromised. Hence, the presence of the iron particulate is also the likely cause of the absence of Odonata in the treatment wetland site ${ }^{[20,30]}$.

Ephemeroptera larvae are typically collectors or scrapers with three characteristically thin, long tails. They are considered the most sensitive of the ETSD group. They are highly vulnerable to turbid conditions, low dissolved oxygen and heavy metals ${ }^{[22,30]}$. For these reasons, mayfly abundance was examined as its own water quality index.

Mayflies abundance: It was also hoped that the Ephemeroptera (mayfly) abundance in Cell 1 would be significantly different from the outlet, indicating improving water quality in the system and the mayfly abundance in the reference site and outlet would be significantly similar, indicating water quality comparable to a pristine wetland. However, this was not demonstrated by the results. Mayfly abundance in the reference site was $13.64 \%$, but no mayflies were identified in either Cell 1 or the outlet of the treatment wetland site. Ephemeroptera breathe through delicate gills which are easily damaged and clogged by particulate matter. Mayflies also require firm substrates to carry out their daily tasks. The high abundance of iron particulate in the treatment wetland makes it an extremely hostile environment for Ephemeroptera to thrive in as it would likely be the cause of irreparable damage to their vital breathing systems, as well as making the substrates critically unstable ${ }^{[22,30]}$. Ephemeroptera are also extremely sensitive to low dissolved oxygen levels. Low dissolved oxygen levels are often the result of organic pollution. High particulate content in waters increases heat absorption which lowers dissolved oxygen levels. In addition, dissolved oxygen is also consumed during iron oxidation $^{[29,30,31]}$. According to Mason ${ }^{[31]}$, mayflies are one of the most sensitive groups to heavy metal contamination in waters. Hence, the presence of the abundant iron particulate in the treatment wetland is the likely cause of the absence of Ephemeroptera in the treatment wetland site.

Trophic structure: In aquatic environments, four major trophic groups of macroinvertebrates exist: scrapers, shredders, collectors and predators. Scrapers are the organisms most often found clinging to rocks, scraping off and feeding on algae for food. Collectors consume fine particulate organic matter (FPOM), usually detritus, either by filter-feeding or obtaining materials from substrates. Shredders consume coarse particulate organic matter (CPOM), such as aquatic plants and detritus through maceration. Finally, predators prey on living animals (typically other macroinvertebrates) for food. Shifts in trophic structure are often indicative of a community responding to an overabundance of a particular food source, or to disturbance ${ }^{[30,31]}$. In the reference wetland, the shredder, scraper, predator and collector ratio was 2:2:21:75, which is normal for natural wetland sites ${ }^{[6,31]}$. In Cell 1, the ratio was 0:2:2:96 and in the outlet the ratio was 0:0:3:97. The functional feeding group ratios in the treatment wetland were dissimilar to the reference site, which can be interpreted for specific water quality indications. Scraper and collector abundances often decrease in response to metal contamination, as metals tend to bind to their food, leading to both acute and chronic toxic effects. However, abundant collectors were sampled in the treatment wetland site, which can be interpreted as an indication that the iron and manganese in the waters are mostly present in their unbioavailable, non-toxic, oxidized states. If abundant reduced iron and manganese were present in the site, collectors would not be abundant ${ }^{[30,31]}$. The lack of scrapers can be explained by the overbearing presence of the oxidized iron particulate. Scrapers feed on periphyton that grows attached to solid objects. Iron precipitate tends to coat sediment, gravel and rocks, limiting the ability of periphyton to grow. The algae that does survive often becomes smothered in floc, making it inconsumable. Shedder functional feeding group shifts are also most commonly a response to a lack or abundance of food. In seeing that the wetland site is only in its second growing season, it has not had much opportunity to build up large amounts of coarse particulate organic matter (CPOM) in the form of leaves and detritus, which is their primary food source $^{[7]}$. However, this does not explain their complete absence from the treatment site. An absence of shredders is also cited as an indication of toxic substances such as metals which often bind to CPOM, resulting in shredder mortalities ${ }^{[7]}$. Iron and manganese 
OnLine J. Biol. Sci., 7 (2): 52-65, 2007

present in the leachate may have bound to their food source, causing toxic effects or their food source may have simply become so smothered in iron particulate and became inaccessible to consume ${ }^{[30]}$. In most circumstances, the feeding group which suffers the highest declines in unhealthy ecosystems is predators. This is because predators tend to be highly sensitive, mostly in part of their larger biomass, their high oxygen demands and bioaccumulation factors. The treatment wetland site supported 2 predators in Cells 1 and 3 predators in the outlet while the reference site supported 21 predators. Their absence is an indication of low dissolved oxygen and potential bioaccumulating chemicals such as persistent organic pollutants (POPs). Interestingly enough, their absence is not indicative of bioavailable metals causing toxicity, as in the case of metal contamination, predator ratios typically appear high against that of the declining scrapers and collectors $^{[7,14]}$. However, the opposite has occurred here, which again supports the conjecture that the majority of metals in the wetland are not bioavailable and not causing toxic effects. The high abundance of oxidized iron particulate in the treatment wetland is associated with various non-toxic, secondary effects such as smothering of eggs, food substrates and habitat, decreasing of dissolved oxygen due to increased water temperatures and the reduction of visibility which affects visual predators. Hence, the iron particulate is also the most likely cause of the disproportionate trophic structures in the treatment wetland site.

Biodiversity: Biological assessments (bioassessments) evaluate the health of an ecosystem by directly measuring the condition of one or more of its taxonomic assemblages compared to that of natural, healthy sites local to the area (reference sites). The major premise of bioassessments is that the community of plants and animals will reflect the underlying health of the ecosystem in which they live.

Biodiversity is often sited as the pre-eminent gauge of biological integrity ${ }^{[32]}$. The derived Shannon-Weiner diversity values $(\mathrm{H})$ for the reference wetland, Cell 1 and outlet area of the treatment wetland indicate that in terms of their aquatic macroinvertebrate populations, the reference wetland is the most diverse (1.115), followed by Cell 1 (0.882) and the outlet (0.675). One of the aims of the study was to create a naturalized treatment wetland site that would have a diverse aquatic macroinvertebrate population similar to that of a pristine, natural wetland site and it was expected that this similarity would increase from Cell 1 to the outlet as the water quality and habitat value of the cells improved. The significance of these differences was tested statistically by comparing the values derived from the Shannon-Weiner diversity index for each site via $t$-tests. The derived hypotheses were:

$\mathbf{H}_{\mathbf{0}}$ : Significant differences exist between the aquatic macroinvertebrate diversities of the three locations (reference wetland, Cell 1 and outlet of treatment wetland)

$\mathbf{H}_{1}$ : No significant differences exist between the aquatic macroinvertebrate diversities of the three locations (reference wetland, Cell 1 and outlet of treatment wetland)

The calculated test statistics must be higher than the critical $t$-values $(p=0.05)$ in order for the null hypotheses to be rejected ${ }^{[24]}$. The t-statistic values of $0.690, \quad 1.595$ and 0.968 obtained for the macroinvertebrate diversity comparisons between the reference wetland and treatment wetland Cell 1, the reference wetland and the treatment wetland outlet and Cell 1 and the outlet respectively, were less than the critical t-values of 1.960 and 1.980 for all the comparisons. Hence, the null hypothesis was not rejected, which implies that there were no significant differences between the aquatic macroinvertebrates diversity at the test sites. However, the reference wetland supported nearly $40 \%$ more families of macroinvertebrates than the outlet and nearly $30 \%$ more families than Cell 1. The macroinvertebrates in the treatment wetland were sampled only during the second growing season of the site. As the vegetation in the treatment wetland matures, superior micro-habitat and water quality improvement is expected to occur. Therefore, it is likely that the macroinvertebrate diversity in the site will improve in subsequent growing seasons.

Natural, healthy wetlands not only support diverse populations of macroinvertebrates, but balanced proportions of species as well ${ }^{[7,14,30]}$. The top taxon in the reference wetland site were the Oligochaeta (aquatic worms) with 33 individuals, the Corixidae (water boatmen) with 17 individuals and the Hirudinea (leeches) with 8 individuals, all of which accounted for $58 \%$ of the sampled population. The top three taxon in Cell 1 of the treatment wetland were the Hyalellidae (scuds) with 30 individuals, the Oligochaeta with 24 individuals and the Corixidae with 10 individuals, all of which accounted for $64 \%$ of the sampled population. Corixidae were found to be abundant in the reference site as well as Cell 1 of the treatment site. This family of insect is notably not dependent on dissolved oxygen levels in the water column, as they breath air from air bubbles held under their wings, which is obtained from 
OnLine J. Biol. Sci., 7 (2): 52-65, 2007

surface air. These insects are very tolerant of chemical and biological stress and are typically capable of surviving in nearly any permanent open-water environment. Although their presence is not cited as a gauge of biological integrity, it does not indicate poor biological health ${ }^{[14,30]}$. Finally, the top three taxon from the treatment wetland outlet were the Hyalellidae with 42 individuals, the Oligochaeta with 15 individuals and the Elmidae (riffle beetles) with 10 individuals, all of which accounted for $67 \%$ of the sampled population. The treatment wetland site supported a high abundance of Hyalellidae, especially in the samples from the outlet. Often, these insects are very abundant in small habitats without fish. In fact, some small, spring-fed streams with thick rooted vegetation and abundant detritus for food support up to 10,000 scuds per $\mathrm{m}^{2}$. They are important to the breakdown of organic matter and are an essential to the diet of many invertebrate predators, including amphibians and waterfowl. Although dominating the treatment wetland site, their high abundance is not indicative of poor biological health ${ }^{[30]}$. The outlet also supported a relatively high abundance of Elmidae larvae. Like the Corixidae, most species of riffle beetle are capable of thriving in both healthy and disturbed systems and are therefore not cited as indicators of biological integrity ${ }^{[30]}$.

The reference wetland site supported higher taxon heterogeneity than both Cell 1 and the outlet and Cell 1 supported slightly higher heterogeneity than the outlet. Both the reference and treatment wetland sites supported high abundances of Oligochaeta. Aquatic worms are typically very abundant in healthy wetlands, especially in deeper areas of the waterbodies. They are actually very important to overall biological health, as their feeding habits cause them to continuously mix the top 5 to $10 \mathrm{~cm}$ of the bottom sediment. This vertical mixing exposes otherwise anaerobic sediments to dissolved oxygen from the waterbody, keeping sediments oxygen-rich, which is vital to a diverse assemblage of organisms. As a result, the presence of aquatic worms is often cited as indicators of biological integrity $^{[30]}$. Hence, their high abundance in the treatment wetland demonstrates that the site does support some semblance of health. It had been hoped the heterogeneity of the macroinvertebrates in the treatment wetland would be similar to that of the reference wetland and that heterogeneity would be improved with the hypothesized improving water quality, but the results revealed that the treatment wetland site lacked the biological integrity conducive to supporting appropriately distributed populations of macroinvertebrates ${ }^{[14,30]}$. However, it is likely that as the system matures, the heterogeneity of the macroinvertebrates population in the site will improve.

\section{CONCLUSIONS}

Aquatic macroinvertebrates monitoring is an excellent indicator of water quality in the wetland and it showed that the water quality improvement was low in the treatment wetland in the initial stage. Chemical analyses of inlet and outlet streams of water showed reductions in manganese, orthophosphate, iron, TSS, TDS and COD of 49.66, 66.66, 67.36, 1.91, 46.37 and $8.33 \%$, respectively. However, the wetland was ineffective in reducing TKN mainly due to depletion of dissolved oxygen (concentration of 4.1-4.4 $\mathrm{mg} \mathrm{L}^{-1}$ ) caused by water stagnation in the site. Hyper-eutrophic conditions as a result of high phosphorous concentrations $\left(0.015-1.38 \mathrm{mg} \mathrm{L}^{-1}\right)$ were detrimental to dragonflies (Leucorrhinia, Libellula), caddisflies (Triaenodes, Oecetis), chironomids (Tanytarsus, Procladius) and fingernail clams (Sphaeriidae). In addition, the overabundant and overwhelming presence of the iron flocs in the wetland system was instrumental in disrupting trophic structure, thereby, affecting the biological integrity of the wetland. However, the biodiversity of the constructed wetland $(0.882-0.675)$ is expected to improve with its maturation, superior micro-habitat and water quality improvement in future.

\section{ACKNOWLEDGMENTS}

This study was made possible through the financial support of the ELJB Foundation of Montréal and the TD Bank Friends of the Environment Foundation of Toronto. The financial support of Killam Trusts of Dalhousie University in the form of a Killam post doctoral fellowship to Dr. M. Verma is highly appreciated.

\section{REFERENCES}

1. EC., 1987. Canadian Wetland Classification System. Ecological Land Classification Series No. 21. National Wetlands Working Group, Land Conservation Branch, Canadian Wildlife Service, Environment Canada, Ottawa, Ontario.

2. Davis, L., 1995. A Handbook of Constructed Wetlands: A Guide to Creating Wetlands for Agricultural Waste, Domestic Wastewater, Coal Mine Drainage and Stormwater in the Mid-Atlantic Region. Vol. 1: General Considerations. Natural Resources Conservation Service, United States 
Environmental Protection Agency, Washington, DC.

3. USEPA., 1995. Ecological restoration: Linking restoration practices to water quality parameters. Technical Report No. EPA 841-F-95-007. United States Environmental Protection Agency, Washington, DC. http://www.epa.gov/OWOW/ NPS/Ecology/chap3.html [2002, 19 September].

4. Lum, K., 1998. The key role of wetlands in addressing the global water crisis. Paper presented at the International Conference on Water and Sustainable Development, March 19-21, France.

5. NRC., 2004. The Atlas of Canada: Wetlands. Natural Resources Canada http://atlas.nrcan.gc. $\mathrm{ca} /$ site/english/learningresources/ theme_modules/ wetlands/index.html\#facts [2007, June 12].

6. Mitsch, W.J. and J.G. Gosselink, 2000. Wetlands. Third edition. John Wiley and Sons, New York, New York.

7. Osmond, D.L., D.E. Line, J.A. Gale, R.W. Gannon, C.B. Knott, K.A. Bartenhagen, M.H. Turner, S.W. Coffey, J. Spooner, J. Wells, J.C. Walker, L.L. Hargrove, M.A. Foster, P.D. Robillard and D.W. Lehning, 1995. WATERSHEDSS: Water, Soil and Hydro-Environmental Decision Support System, Department of Biological and Agricultural Engineering <http://www.bae.ncsu.edu/bae/>, North Carolina State University, Raleigh, North Carolina. http://www.water. ncsu.edu/watershedss/ [2007, 24 July].

8. RCW., 2002. Background papers on wetland values and functions: Reservoirs of biodiversity. Ramsar Convention on Wetlands, Gland, Switzerland .http://www.ramsar.org/info/values _biodiversity_e.htm [2007, 24 July].

9. Nivala, J., M.B. Hoos, C. Cross , S. Wallace and G. Parkin, 2007. Treatment of landfill leachate using an aerated, horizontal subsurface-flow constructed wetland. Sci. Total Environ., 380: 19-27.

10. Rader, R.B., D.P. Batzer and S.A. Wissinger, 2001. Bioassessment and Management of North American Freshwater Wetlands. John Wiley and Sons, New York, New York.

11. Batzer, D.P., R.B. Rader and S.A. Wissinger, 1999. Invertebrates in Freshwater Wetlands of North America: Ecology and Management. John Wiley and Sons, New York, New York.

12. Cabecinha, E., P. Silva-Santos, R. Cortes and J.A. Cabral, 2007. Applying a stochastic-dynamic methodology (StDM) to facilitate ecological monitoring of running waters, using selected trophic and taxonomic metrics as state variables. Ecological Modelling (In Press).
13. Pinel-Alloul, B., G. Méthot, L. Lapierre and A. Willsie, 1995. Macroinvertebrate community as a biological indicator of ecological and toxicological factors in lake Saint-François, Québec. Eviron. Pollut., 91: 65-87.

14. USEPA., 2002. Methods for evaluating wetland condition: Developing an invertebrate index of biological integrity for wetlands. Technical Report No. EPA-822-R-02-019. United States Environmental Protection Agency, Washington, DC. http://www.epa.gov/waterscience/criteria /wetlands/9Invertebrate.pdf [2003, 22 January].

15. HLIS., 1992. Aerial photograph 183, 92329-7. 9207-16, 11D-12, 111-65. Halifax Land Information Services, Government of Nova Scotia, Halifax, Nova Scotia.

16. Ghaly, A.E. and R. Côté, 2001. Engineered wetland technology for treatment of industrial park contaminants: Technical progress report. Dalhousie University, Halifax, Nova Scotia.

17. Lewis, M.C.F., B.B. Taylor, R.R. Stea, G.G.J. Fader, R.J. Horme, S.G. MacNeil and J.G. Moore, 1998. Earth science and engineering: Urban development in the metropolitan Halifax region. Minerals and Energy Branch, Nova Scotia Department of Natural Ressources, Halifax, Nova Scotia.

18. APHA., 2002. Standard Methods for the Examination of Water and Wastewater, 20th Edn. American Public Health Association, Baltimore, Maryland.

19. EC., 1988. Nova Scotia Wetlands Atlas. Wetlands Mapping Protection Program, Canadian Wildlife Service, Environment Canada, Sackville, Nova Scotia.

20. Peckarsky, B.L., P.R. Fraissinet, M.A. Penton and D.J. Conklin Jr., 1990. Freshwater Macroinvertebrates of Northeastern North America. Cornell University Press, Ithaca, New York.

21. Kirsch, P.E., 1999. Benthic Macroinvertebrate Diversity and Biotic Indices Analysis of Lakes Wrights, Springfield, McGrath, Kearney and Morris and an Upgraded Analysis of Lakes Dollar, Russell, Stillwater, Papermill and Kinsac within the Halifax Regional Municipality (HRM): Technical report, Soil and Water Conservation Society of Metro Halifax, Dartmouth, Nova Scotia.

22. Mandaville, S.M., $2002 . \quad$ Benthic Macroinvertebrates in Freshwaters: Taxa Tolerance Values, Metrics and Protocols. Technical report, Soil and Water Conservation Society of Metro Halifax, Dartmouth, Nova Scotia. 
OnLine J. Biol. Sci., 7 (2): 52-65, 2007

23. Hynes, K.E., 1998. Benthic Macroinvertebrate Diversity and Biotic Indices for Monitoring of 5 Urban and Urbanizing Lakes within the Halifax Regional Municipality (HRM). Technical report, Soils and Water Conservation Society of Metro Halifax, Dartmouth, Nova Scotia.

24. Murphy, S.D., 1999. Notes: ERS 380 Restoration Ecology Course Reader. University of Waterloo, Waterloo, Ontario.

25. Cousins, S.H., 1991. Species diversity measurement: Choosing the right index. Trends. Ecol. Evolut., 6: 190-192.

26. CCME., 2006. Canadian water quality guidelines for the protection of aquatic life. Summary table. Canadian Council of Ministers of the Environment, Winnipeg, Manitoba. http://www.ccme.ca/assets /pdf/ceqg_aql_smrytbl_e_6.0.1.pdf [2007, 24 July].

27. USEPA., 2002. Methods for evaluating wetland condition: Introduction to wetland biological assessment. Technical Report No. EPA-822-R-02014. United States Environmental Protection Agency, Washington, DC. http://www.epa.gov /waterscience/ criteria/wetlands/1Introduction.pdf [2003, 22 January].
28. Barbour, M.T., J. Gerritsen, B.D. Snyder and J.B. Stribling, 1999. Rapid Bioassessment Protocols for Use in Streams and Wadeable Rivers: Periphyton, Benthic Macroinvertebrates and Fish, second edition. Technical Report No. EPA 841-B-99-002. Office of Water, U.S. Environmental Protection Agency, Washington, DC.

29. Boulton, A.J. and M.A. Brock, 1999. Australian Freshwater Ecology: Processes and Management. Cooperative Research Centre for Freshwater Ecology and Gleneagles Publishing, Canberra, Australia.

30 Voshell, R.J., 2002. A Guide to Freshwater Invertebrates of North America. McDonald and Woodward Publishing, Blacksburg, Virginia.

31. Mason, C.F., 1998. Biology of Freshwater Pollution, third edition. Addison Wesley Longman Limited, London, England.

32. Daigle, J.M. and D. Havinga, 1996. Site Level Restoration Planning And Implementation. In: Restoring Nature's Place: A Guide to Naturalizing Ontario's Parks and Greenspace. Daigle, J.M. and D. Havinga (Eds.). Ontario Parks Association, Toronto, Ontario, pp: 61-92. 